\title{
Evaluation of the effect of infill walls on seismic performance of RC dual frames
}

\author{
M. S. Razzaghi • M. Javidnia
}

Received: 4 November 2014/ Accepted: 12 January 2015/Published online: 27 January 2015

(c) The Author(s) 2015. This article is published with open access at Springerlink.com

\begin{abstract}
Masonry infill walls have many beneficial and disadvantageous effects on seismic performances of RC frames. Despite such remarkable effects, practicing engineers usually neglect the effects of infill walls on seismic behavior of structures. This study aims to demonstrate that neglecting the effects of infill walls during the nonlinear dynamic analysis of the RC frames may lead to the dramatic misunderstanding the seismic performance of the structure. To this end seismic response of 18 models of the same structure and different arrangements of the infill walls to four different ground motions were investigated using PERFORM 3D software. Results of this study revealed that changing the arrangement of infill walls may change the damage state of the building during an earthquake.
\end{abstract}

Keywords Infill wall - Seismic performance - Damage · RC frame · Uncertainty

\section{Introduction}

Performance of infilled structures during the past earthquakes revealed that masonry infill walls play a vital role in seismic performance of structures (Eshghi et al. 2004; Hosseni Hashemi and Hassanzadeh 2008; Hussein and Kabeyasawa 2004). Hence, there is a worldwide interest in evaluating the effects of infill walls on seismic performance of framed structures (Mosalam et al. 1997; Hossein and Kabeyasawa 2004; Korkmaz et al. 2007; Koutromanos et al. 2011). Despite significant amount of research, there is no consensus on whether the infill walls play beneficial or

M. S. Razzaghi $(\bowtie) \cdot$ M. Javidnia

Department of Civil Engineering, Qazvin Branch, Islamic Azad

University (QIAU), Nokhbegan Blvd, Qazvin, Iran

e-mail: razzaghi.m@gmail.com disadvantageous role in vulnerability of structures (Pujol and Fick 2010). Some of the researches have presented the beneficial effects of infill walls on seismic performance of structures (Murty and Jain 2000). Meanwhile some other researchers demonstrated that infill walls increase the seismic vulnerability of structures (Sezen et al. 2003).

In fact, masonry infill walls noticeably increase the initial stiffness of the frame and thus change the lateral load transfer mechanism (Murty and Jain 2000; Kaushik et al. 2006; Moghaddam and Dowling 1987). On the other hand the irregularity associated with uncertain location of infill walls may make unwanted effects on overall behavior of structures (Kaushik et al. 2006). Furthermore sudden decrease in stiffness due to failure of infill walls may cause several damages to buildings (Paulay and Priestley 1992). It should be noted that practicing engineers usually neglect the effects of infill walls on seismic behavior of structures. Thus, the beneficial and disadvantageous effects of infill walls on seismic performance of the frames may be neglected during the design procedure.

This study aims to investigate the effect of uncertain arrangement of masonry infill walls on seismic performance of RC frames. To this end nonlinear response history of a particular RC dual frame with different possible arrangements of infill walls have been investigated.

\section{Description of the prototype frame}

The prototype frame is an existing commercial-residential building located in Ercis city in Turkey. The building was moderately damaged during the 23 October, 2011 earthquake in Van province. The building was a 7 story having a basement, a commercial ground floor and five residential floors. The lateral resisting system is RC dual frames in both principal directions. The basement has rigid $\mathrm{RC}$ 
retaining walls continuously interconnected to the frame all around its perimeter. The general view of the building and the plan of the building in ground and residential floors are indicated in Figs. 1 and 2, respectively. All of the columns and beams have rectangular cross sections. The dimensions of the columns and beams were constant in different floors $\left(30 \times 80 \mathrm{~cm}^{2}\right.$ in columns and $30 \times 60 \mathrm{~cm}^{2}$ in beams). The compressive strength of the concrete is $21 \mathrm{MPa}$. The masonry infill walls were constructed by lightweight cement blocks with $20 \mathrm{~cm}$ thickness, $4 \mathrm{MPa}$ compressive strength and modulus of elasticity of 2,200 MPa.

\section{Numerical modeling}

Nonlinear response history analyses were conducted to investigate the effect of uncertain arrangement of infill walls on seismic performance of the infilled RC frames. To this end PERFORM-3D software (PERFORM-3D 2008) was used. Fiber elements were used to model RC shear walls and columns. Furthermore two node beam elements were used to model beams. It should be noted that the properties of plastic hinges have been assigned to the beam elements according to FEMA 356 (FEMA 2000). The schematic of a moment rotation curve and acceptance criteria for RC beams is indicated in Fig. 3. FEMA 356 considerations were used to calculate the bending capacity of RC beams. It is worth mentioning that the reducing effect of the number of cycles on the member stiffness was considered using energy loss coefficient. The energy loss coefficient indicates the ratio of the curve area between the two successive loops. Shear infill elements were used for modeling masonry infill walls. Masonry infill walls usually perform as a secondary bracing system for the building (Hosseni Hashemi and Hassanzadeh 2008). Hence, the lateral rigidity of a masonry panel can be considered by assuming a compression strut with a width "a", and can be calculated as follows (FEMA 2000):

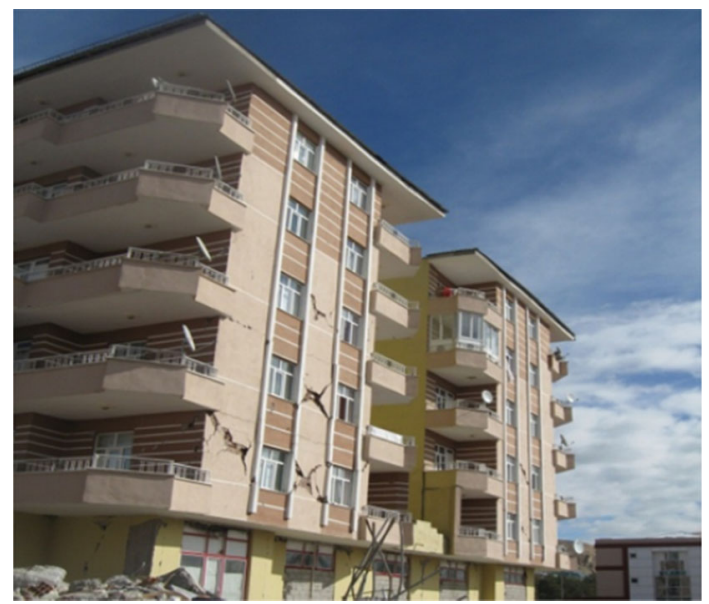

Fig. 1 A view of the prototype building

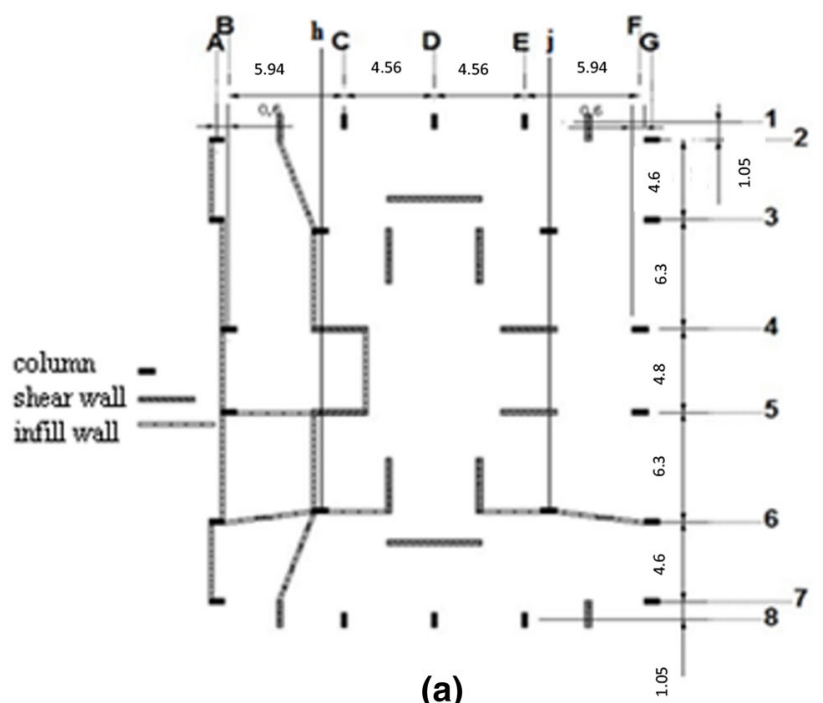

(a)
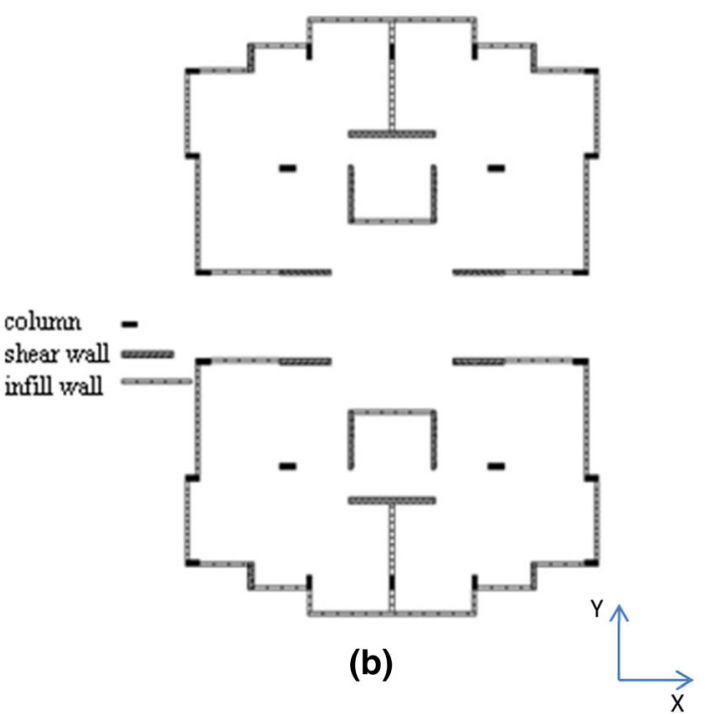

Fig. 2 Location of columns, shear walls and infill walls in a residential floors, $\mathbf{b}$ commercial floor

$\alpha=0.175 D\left(\lambda_{1} H\right)^{-0.4}$

where $H$ is the height of the column and $D$ is the diagonal length of the panel. Furthermore $\lambda_{1}$ can be calculated as follows:

$\lambda_{1}=\left[\frac{E_{\mathrm{m}} t \sin 2 \theta}{4 E_{\mathrm{fe}} I_{\mathrm{col}} h}\right]^{\frac{1}{4}}$.

where $E_{\mathrm{m}}$ and $E_{\mathrm{fe}}$ denote elastic modulus of infill material and the frame materials, respectively, $t$ is the thickness of infill wall, $I_{\mathrm{col}}$ is the column moment inertia and $h$ is the infill height. Furthermore $\theta$ can be calculated as follows:

$\theta=\tan ^{-1}\left(\frac{h}{l}\right)$ 


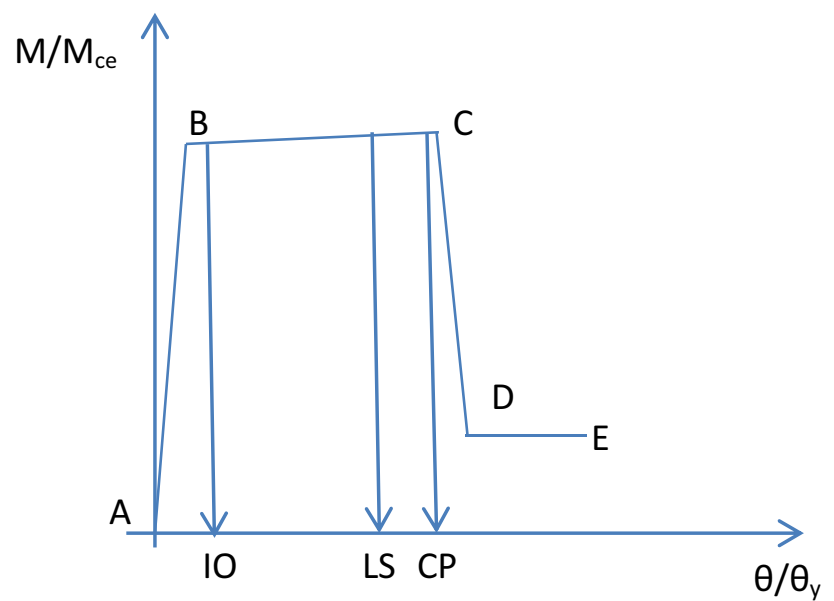

Fig. 3 Schematic of moment-rotation curves and acceptance criteria for RC beams

Table 1 Descriptions of the models

\begin{tabular}{ll}
\hline Model & Description \\
\hline Org & Prototype building in its actual situation \\
Test-1 & Without any infill wall in interior panels of the ground \\
Test-2 & Without any infill wall in the ground floor \\
Test-3 & $\begin{array}{c}\text { Adding infill walls to the perimeter of the prototype } \\
\text { building in ground floor }\end{array}$
\end{tabular}

Test-4 Removing the internal infill panels from "test-4" model

Test-5 All perimeter infill walls in ground floor were removed from the "Org" model

Test-6 All perimeter infill walls parallel to $X$ direction in ground floor were removed from "test-3" model

Test-7 All internal infill walls along with perimeter infill walls parallel to $X$ direction in ground floor were removed from "test-3" model

Test-8 All perimeter infill walls parallel to $Y$ direction in ground floor were removed from "test-3" model

Test-9 All internal infill walls along with perimeter infill walls parallel to $Y$ direction in ground floor were removed from "test-3" model

Test-10 Adding interior infill walls to "test-3" model to make its infill walls symmetric

Test-11 The prototype building without any infill wall

Test-12 Perimeter infill walls were removed from "test-10" model in all stories

Test-13 All interior infill walls were removed from "test-10" in all stories

Test-14 Perimeter infill walls were removed from "Org" model in all stories in $Y$ direction

Test-15 Perimeter infill walls were removed from "Org" model in all stories in $X$ direction

Test-16 Perimeter infill walls were removed from "Org" model in all stories in $Y$ direction along with all internal infill panels

Test-17 Perimeter infill walls were removed from "Org" model in all stories in $X$ direction along with all internal infill panels
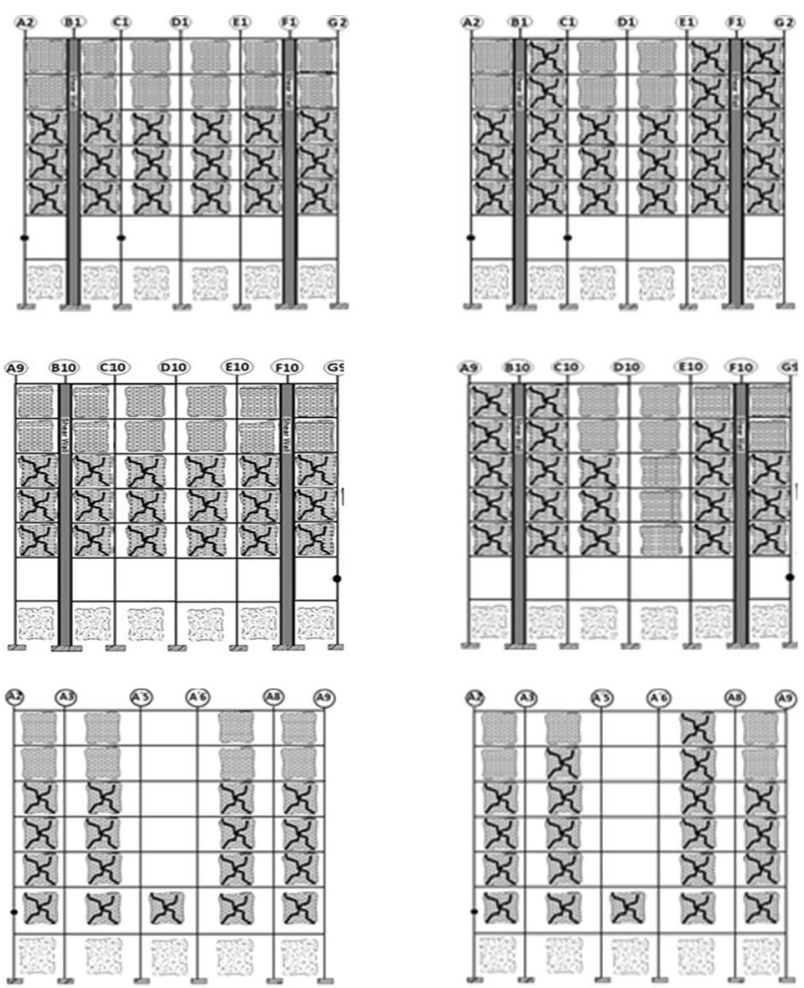

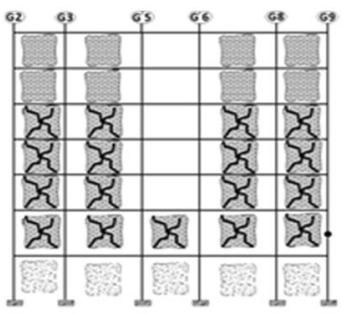

(a)

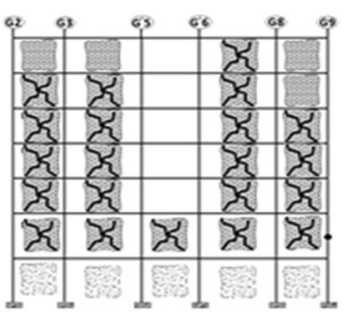

(b)

$$
\begin{aligned}
& \text { - Damaged infill walls } \\
& \text { - Plastic hinges at the end of Columns } \\
& \text {-2 Retaining walls }
\end{aligned}
$$

Fig. 4 Comparing the damage observed in $\mathbf{a}$ the prototype and $\mathbf{b}$ the numerical model

Table 2 Description of the selected ground motions

\begin{tabular}{lllll}
\hline Seismic event & Year & Country & Magnitude & PGA (g) \\
\hline Van & 2011 & Turkey & 7.2 & 0.17 \\
Northridge & 1994 & USA & 6.7 & 0.51 \\
El Centro & 1940 & USA & 7.1 & 0.27 \\
Chi-Chi & 1999 & Taiwan & 7.6 & 0.095 \\
\hline
\end{tabular}

where $l$ is the width of the infill panel.

Finally the infill rigidity can be calculated as follows:

$K=E_{\mathrm{m}} \alpha t / D$

For those infill panels that have a opening, a modified lateral rigidity should be used. To this end the reduction coefficient should be applied to the width of the diagonal 
strut. The reduction coefficient, $R$, can be calculated as follows (Al-Chaar 2002):

$R=0.6\left(\frac{A_{\text {open }}}{A_{\text {panel }}}\right)^{2}-1.6\left(\frac{A_{\text {open }}}{A_{\text {panel }}}\right)+1$

where $A_{\text {open }}$ and $A_{\text {panel }}$ are areas of the opening and the panel, respectively.An infill cracking resistance can be calculated as follows:

$R_{\mathrm{Cr}}=a t f_{\mathrm{m}}^{\prime}$

where $f_{\mathrm{m}}^{\prime}$ denotes the compressive strength of the infill material. Furthermore the shear strength of the infill panel can be calculated as follows:

$R_{\text {shear }}=A_{\mathrm{n}} f_{\mathrm{v}}^{\prime}$

where $A_{\mathrm{n}}$ is the area of the cross section of mortar between adjacent rows of the infill panel and $f_{\mathrm{v}}^{\prime}$ is the shear strength of the infill panel. To calculate the infill shear strength the Mohr-Coulomb criterion was used. To this end, the mortar adhesive coefficient, $\tau$, can be calculated according to (Paulay and Priestly 1992):

$\tau=0.04 f_{\mathrm{m}}^{\prime}$

Furthermore, to calculate the friction coefficient, $\mu$, the following relation can be used (Chen 2003):

$\mu=0.654+0.00515 f_{\mathrm{j}}^{\prime}$ where $f_{\mathrm{j}}^{\prime}$ is the compressive strength of the mortar between the infill rows. Finally the infill shear strength can be calculated by summation of $\tau$ and $\mu \sigma$; where $\sigma$ is the vertical compressive stress.

To investigate the effects of the infill walls on seismic performance of the RC-framed structures, 17 possible arrangements of the infill walls were considered in addition to the prototype building in its actual situation. The descriptions of these models are presented in Table 1.

\section{Model verification}

To verify the model, response history of the building to the Van earthquake was estimated using nonlinear response history analysis. Results of the numerical analysis were compared to the actual performance of the structure. To this end the acceleration time history of the ground motion recorded in Muradiyeh station was used. It should be noted that during the Van earthquake of October 23, 2011 the prototype model was moderately damaged. The columns in the ground floor were damaged and plastic hinges were formed in some of the columns. No observable damage had occurred in RC beams but some of the infill walls were cracked. Results of the numerical analysis are in noticeable agreement with actual performance of the structures during the earthquake. Figure 3 indicates the damaged columns and infill walls in the prototype and the numerical model.
Fig. 5 Relative energy dissipation in structural elements and infill walls due to a Van earthquake b Northridge Earthquake c El-Centro earthquake d Chi-Chi earthquake
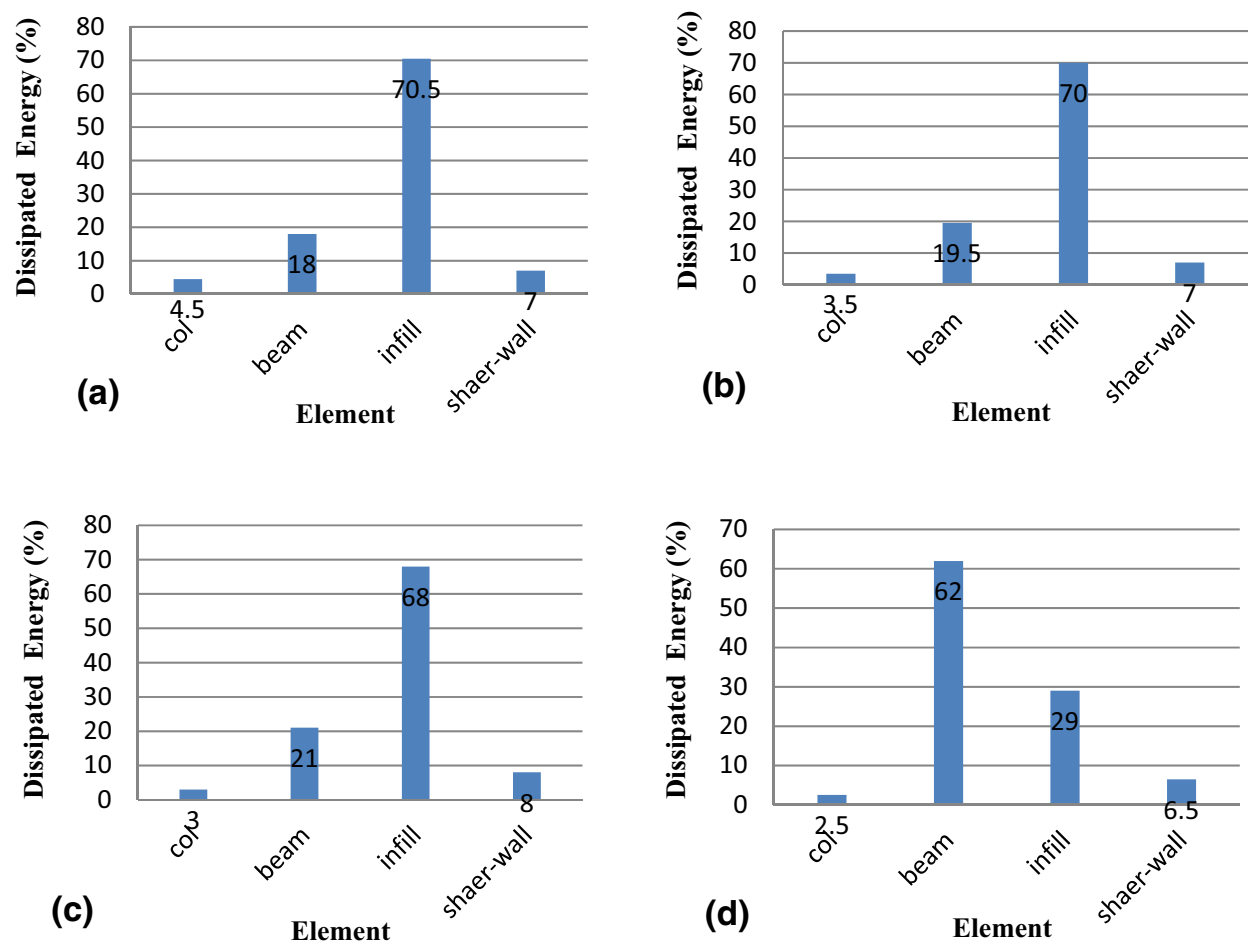

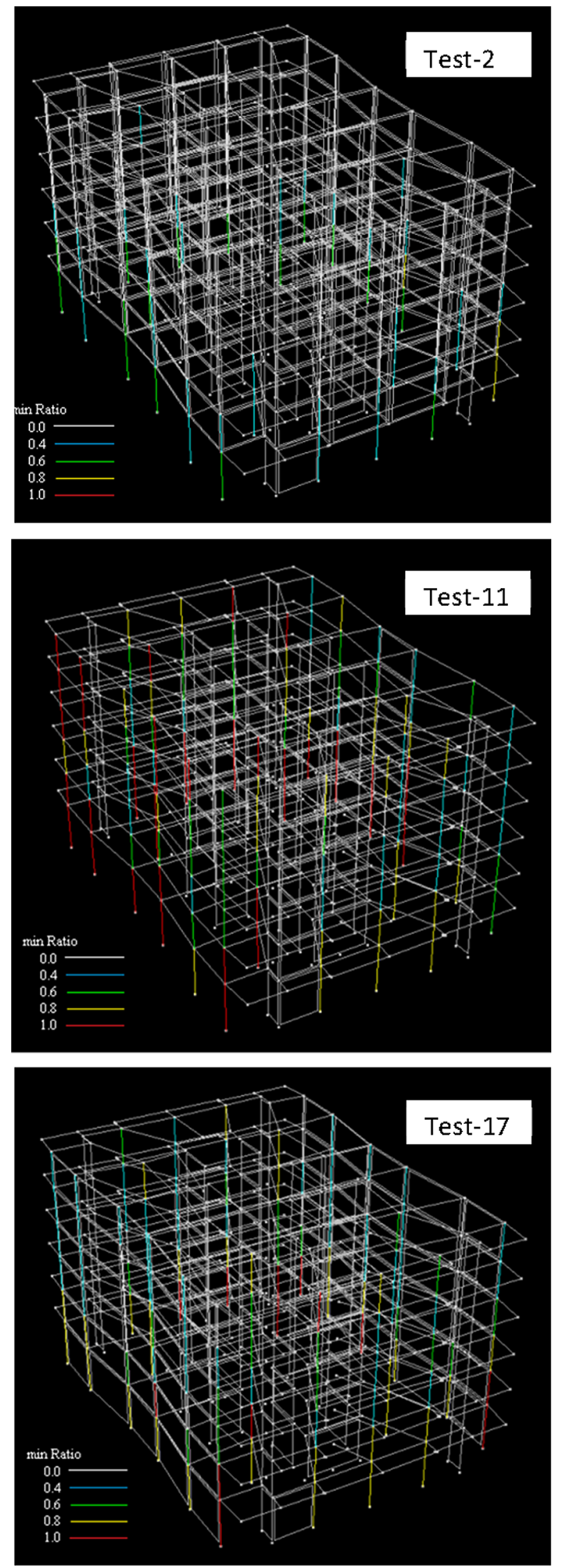

Fig. 6 Comparing the performance of the structure in various models

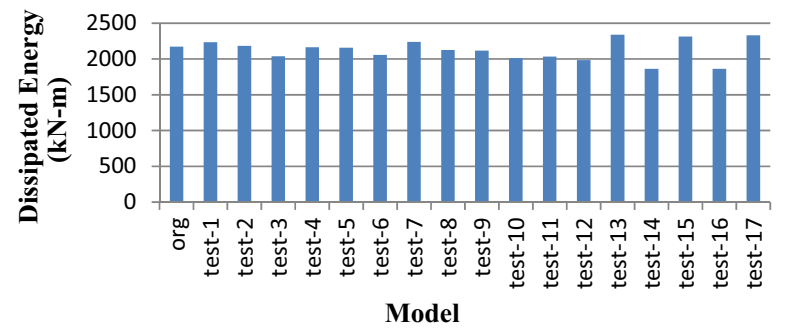

(a)

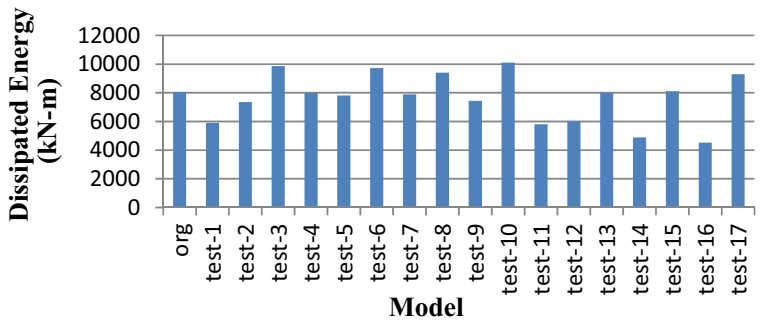

(b)

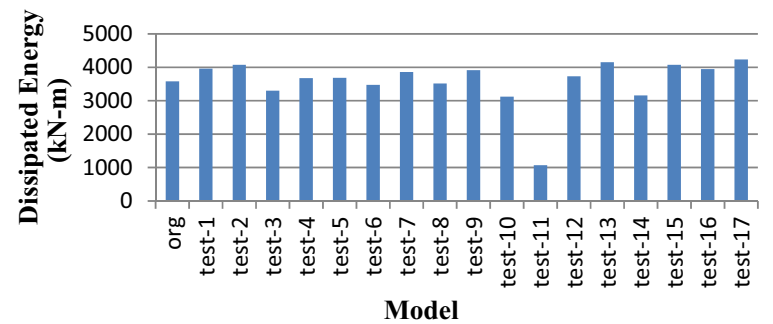

(c)

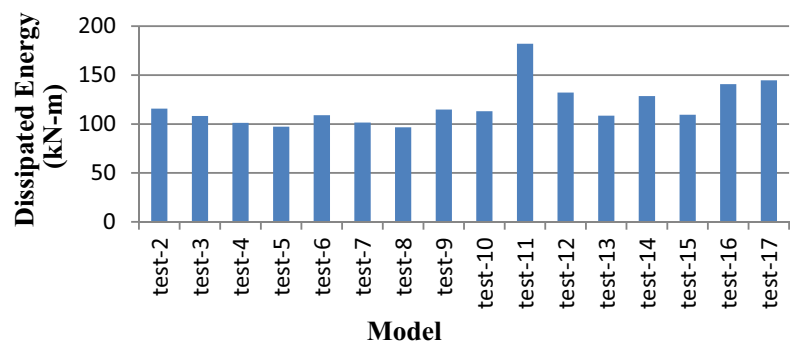

(d)

Fig. 7 Variation of the cumulative dissipated energy in various models in a Van earthquake b Northridge Earthquake c El-Centro earthquake d Chi-Chi earthquake

As indicated in Fig. 4, the numerical model has accurately estimated the location of plastic hinge. Furthermore in most of the infill walls the damage estimated by the numerical model was accurate. It is worth mentioning that it seems that the main reason for damage to columns in the ground floor is soft story effect due to lack of infill walls in the ground floor.

\section{Response history analysis}

Nonlinear response history analyses were performed to investigate the effect of masonry infill walls on seismic 
performances of RC buildings. To this end acceleration time history of four happened earthquakes was used (See Table 2). Figure 5 indicates the relative energy dissipation in structural elements and infill walls in the prototype (the "Org" model) due to the different ground motions. As indicated in this figure infill walls play a vital role in energy dissipation during an earthquake. Results of the numerical analyses revealed that the location of the plastic hinges in the structural elements may dramatically change by varying the arrangement of the infill walls. For example as indicated in Fig. 6, in model "Test 17" the plastic hinges occurred in many of the perimeter columns in different floors. Meanwhile as shown in Fig. 7, in model "Org" the plastic hinges were observed only in the ground floor. Figure 6 shows the demand-to-capacity ratio (DCR) of the columns in three different models in life safety (LS) limit state due to the Van earthquake. As indicated in Fig. 5 the behaviors of the structures remarkably differed in different models. It should be noted that most of the models meet the LS limit state but some of them experienced the immediate occupancy (IO) limit state. In other words considering the effect of infill walls in the nonlinear response history analysis may dramatically affect the seismic performance of the structure. The cumulative energy dissipations in all of the models during the selected earthquakes are shown in Fig. 7. As indicated in Fig. 7 the cumulative dissipated energy in different arrangements of the infill walls may vary up to $400 \%$.

\section{Conclusions}

Nonlinear response history analyses were performed to investigate the effects of the arrangements of the infill walls in seismic performance of infill walls in RC dual frames. To this end an existing RC building which was damaged during the 23 October 2011 Van earthquake was considered. The building was numerically modeled in its actual situation and 17 other arrangements of the infill walls. In addition to the van earthquake, the response histories of all of the models were estimated due to the three other ground motions. Results of this study revealed that infill walls play a vital role in seismic performance of the $\mathrm{RC}$ buildings. It was shown that noticeable changes may occur in seismic performance (e.g., experienced damage state, energy dissipation, etc.,) of the same structure with different arrangements of the infill walls. In other words, neglecting the effects of the infill walls in nonlinear dynamic analysis may lead to noticeable misunderstanding the seismic performance of the structure.

Open Access This article is distributed under the terms of the Creative Commons Attribution License which permits any use, distribution, and reproduction in any medium, provided the original author(s) and the source are credited.

\section{References}

Al-Chaar G (2002) Evaluating strength and stiffness of unreinforced masonry infill structures. US army corps of engineers

Almusallam TH, Al-Salloum YA (2007) Behavior of FRP strengthened infill walls under in-plane seismic loading. J Compos Constr 11(3):308-318

Binici B, Ozcebe G, Ozcelik R (2007) Analysis and design of FRP composites for seismic retrofit of infill walls in reinforced concrete frames. Compos B Eng 38(5):575-583

Chen Y (2003) Seismic evaluation of RC buildings infilled with brick walls. Ph.D. thesis. National Cheng-Kung Univ., Tainan

Eshghi S, Zare M, Assadi K, Razzaghi M, Ahari M, Motamedi M (2004) Reconnaissance report on 26 December 2003 Bam earthquake. International Institute of Earthquake Engineering (IIEES)

FEMA-356 (2000) Prestandard and commentary for the seismic rehabilitation of buildings. Building Seismic Safety Council, Washington (DC)

Hossein M, Kabeyasawa T (2004) Effect of infill masonry walls on the seismic response of reinforced concrete buildings subjected to the 2003 Bam earthquake strong motion: a case study of Bam telephone center

Hosseini Hashemi B, Hassanzadeh M (2008) Study of a semi-rigid steel braced building damaged in the Bam earthquake. J Constr Steel Res 64(6):704-721

Kaushik HB, Rai DC, Jain SK (2006) Code approaches to seismic design of masonry-infilled reinforced concrete frames: a state-ofthe-art review. Earthq Spectra 22(4):961-983

Korkmaz KA, Demir F, Sivri M (2007) Earthquake assessment of R/C structures with masonry infill walls. Int J Sci Technol 2(2):155-164

Koutromanos I, Stavridis A, Shing PB, Willam K (2011) Numerical modeling of masonry-infilled RC frames subjected to seismic loads. Comput Struct 89(11):1026-1037

Moghaddam HA, Dowling PJ (1987) The State of the Art in Infilled Frames, ESEE Research Report No. 87-2, Imperial College of Science and Technology, Civil Eng. Department, London

Mosalam KM, Ayala G, White RN, Roth C (1997) Seismic fragility of LRC frames with and without masonry infill walls. J Earthq Eng 1(4):693-720

Murty CVR, Jain SK (2000) Beneficial influence of masonry infill walls on seismic performance of RC frame buildings. In: 12th World Conference on Earthquake Engineering, Auckland

Paulay T, Priestley MJN (1992) Seismic design of reinforced concrete and masonry buildings

PERFORM-3D user guide (2008) Nonlinear analysis and performance assessment for 3D structures (user guide and getting start), version 4

Pujol S, Fick D (2010) The test of a full-scale three-story RC structure with masonry infill walls. Eng Struct 32(10):3112-3121

Razzaghi MS, Ghafory-Ashtiany M (2012) A Preliminary reconnaissance report on August 11th 2012, Varzaghan-Ahar twin earthquakes in NW of Iran. Report of International Association of Seismology and Physics of the Earth's Interior

Sezen H, Whittaker AS, Elwood KJ, Mosalam KM (2003) Performance of reinforced concrete buildings during the August 17, 1999 Kocaeli, Turkey earthquake, and seismic design and construction practise in Turkey. Eng Struct 25(1):103-114 